\title{
When Do You Use a Jobber?
}

By JOHN VEENSTRA AND LOIS MAI

A CQUISITION LIBRARIANS must ask themselves many times each day "Shall I buy direct, or through a jobber?" The old theory whereby a library used two or three jobbers for all its orders can no longer be considered wise purchasing. As the modern librarian places his orders, he must evaluate each order against the three basic problems: (1) delivery time, (2) discount, and (3) ease of processing. Each point is important and can mean a sizable saving for the library, either directly by discount or by time saved, or indirectly by eliminating wear and tear on the staff. A prime responsibility of every acquisition officer is this careful and judicious use of the library's money so the generally meager funds may be spread to the utmost.

Unfortunately the majority of the library literature on acquisitions scarcely touches this area of dealer selection or service evaluation. The advice given is usually for a library to find a reliable jobber and buy the bulk of its books through him. ${ }^{1}$ A continuing evaluation of dealers and their services is expected of each acquisition department. Since publishers frequently revise their discounts and strive to improve their shipping and billing procedures, their service must be periodically compared with the jobber's service.

In an effort to re-examine book purchasing at the Purdue University libraries, a comparison was made of our American jobbers' and publishers' discounts and delivery time for a year. Of course, every library has its own subject areas of emphasis and our evaluation

1 Maurice F. Tauber. Technical Services in Libraries (New York: Columbia University Pr., 1953), pp. 44-46.
Mr. Veenstra is Head, Order Unit, and Miss Mai is Cataloger, Purdue University Libraries.

must be weighed with consideration of our emphasis. Since the Purdue libraries buy heavily in science and technology with only a minor concentration on trade books, the same results may not have been reached by our survey as might have been reached by that of a library geared more towards the humanities. Because of our subject emphasis the majority of our purchases are on shortdiscount lists. Perhaps that is why the results of our survey cause us to question the value of using a jobber for the majority of our books.

In order to show the reasons for questioning the jobber's services for our particular circumstances, an abbreviated table of the results of our survey is shown here. The average discount from the publisher is cited, followed by the average discount given for the same publisher's books by one of the major jobbers. This is followed by the respective delivery time of each. Publishers cited are those that publish particularly in the scientific and technological fields.

In answer to our figures given below, jobbers often point out that the ease of handling one invoice and only one check quite outweighs the other savings. Our first response to this is that publishers are generally quite willing to bill periodically on one long invoice if this is preferred although our feeling is that lengthy invoices can cause extra compli- 


\begin{tabular}{|c|c|c|c|c|}
\hline \multirow[t]{2}{*}{ Publisher } & \multicolumn{2}{|c|}{ Discounts (Per Cent) } & \multicolumn{2}{|c|}{ DELIVERY Time (Days) } \\
\hline & Direct & Jobber & Direct & Jobber \\
\hline Academic . & 10 & 5 & 23.1 & 55.0 \\
\hline Addison Wesley ............. & 10 & 5 & 11.3 & 54.0 \\
\hline Appleton $\ldots \ldots \ldots \ldots \ldots \ldots$ & 20 & 13.5 & 10.0 & 35.8 \\
\hline Holt $\ldots \ldots \ldots \ldots \ldots \ldots \ldots \ldots$ & 20 & 14 & 13.8 & 40.6 \\
\hline Houghton-Mifflin $\ldots \ldots \ldots \ldots \ldots$ & 25 & 27 & 8.6 & 30.7 \\
\hline Interscience $\ldots \ldots \ldots \ldots \ldots \ldots$ & 10 & 5 & 12.7 & 48.0 \\
\hline Irwin $\ldots \ldots \ldots \ldots \ldots \ldots$ & 15 & 8 & 9.8 & 28.5 \\
\hline McGraw $\ldots \ldots \ldots \ldots \ldots \ldots$ & 20 & 10 & 12.7 & 45.2 \\
\hline Macmillan . & 25 & 14 & 13.1 & 27.8 \\
\hline Prentice-Hall . . . . . . . . . . . & $15^{*}$ & 7 & 18.8 & 20.8 \\
\hline Saunders ................. & 10 & 8 & 8.3 & 50.0 \\
\hline Thomas $\ldots \ldots \ldots \ldots \ldots \ldots \ldots$ & 10 & 8 & 12.3 & 20.0 \\
\hline Van Nostrand $\ldots \ldots \ldots \ldots \ldots \ldots$ & 15 & 17 & 13.0 & 44.0 \\
\hline Wiley ......... & 10 & 5 & 11.6 & 25.7 \\
\hline
\end{tabular}

* Prentice-Hall gives an additional discount to libraries by charging text copy rate.

cations. How many long invoices are held up in the acquisition department because of missing books, wrong editions sent, incorrect billing, etc? It is easier to correct and process a smaller invoice. Unless the procedure for processing these invoices is very complicated, a large number of short invoices need present no greater problem then one long invoice. Also in many cases the processing of these invoices can be streamlined so that the problem is lessened. An example of the value of dealing directly can readily be seen when our savings through McGraw-Hill alone in a year's time will be over $\$ 600.00$.

There are other features that cause one to turn to the publisher. Jobbers will report "Cancelled, publisher and we are out of stock." In the majority of cases it has been our experience that if we in turn order the same book from the publisher, he will supply it. Many dealers will also cancel books that are "not yet published" whereas the publisher will usually supply when published. Standing orders are frequently a problem when placed through a jobber. The publisher will answer more quickly and better than the jobber on follow-ups. In general the performance of the publisher is preferred to that of the jobber. We are aware that the recent American Booksellers' Association conference led to other conclusions, but perhaps its inspection was centered on trade-book rather than technical-book publishers.

It is understood that the jobber is in a pinch. His raison-d'etre must be for the services he performs, and many cannot afford to give any frills to their service and continue to stay in business. As the sales manager of one of the largest jobbers told us, "We try to stay ahead of the pack, and that's all." The jobber cannot afford to stock titles unless the demand is great. Science and technology books are not in great enough demand, so they are not stocked and thus delivery is slow. Single copy orders cut the jobber's discount, so they must be stockpiled until the dealer has five or ten orders for the same book or books of the same publisher and can take advantage of a more favorable discount. Most jobbers operate on a 15 per cent margin and cannot afford to spend any extra money on extra services. One large jobber whom we tried reported he could not cite our order number on the invoices even though he knew this would mean the loss of our proposed business with him, which would have amounted to an estimated $\$ 25,000.00$ yearly. It is re- 
grettable, but true, that the economies forced on the jobber often causes added problems to libraries.

This survey has been very helpful for us. Our delivery time has been cut, and our discounts have increased. The faculty is pleased with the prompter service. Control over our funds has become tighter since we can better predict costs. If a dealer comes to talk with us about his services, we can also be specific as to discounts and delivery time and require definite commitments. We will continue to order current popular titles by major American publishers through a jobber. All other orders for American books that are in print can generally be placed more advantageously directly with the publisher.

Many librarians are familiar with the Book Buyer's Handbook issued by the American Booksellers Association. As stated in the Reader's Adviser and Bookman's Manual ${ }^{2}$ this handbook is "a guide to publishers, their discounts, terms, policies, and trade features, issued in ring-binder format with correction sheets to be supplied from time to time." If acquisition librarians had access to a similar tool, surveys such as ours would be easier to make, and the order librarian could better evaluate his purchasing.

2 Hester R. Hoffman, The Reader's Adviser and Bookman's Manual, (New York: Bowker, 1960), p. 19.

\section{Fair Copying}

Forty-five members of the Association of American University Presses have signed a "Resolution on Permissions (designed to reduce red tape when it is necessary for a scholar to cite the work of others) agreeing:

"1. That publications issued under our imprints may be quoted without specific prior permission in works of original scholarship for accurate citation of authority or for criticism, review, or evaluation, subject to the conditions listed below.

"2. That appropriate credit be given in the case of each quotation.

"3. That waiver of the requirement for specific permission does not extend to quotations that are complete units in themselves (as poems, letters, short stories, essays, journal articles, complete chapters or sections of books, maps, charts, graphs, tables, drawings, or other illustrative materials), in whatever form they may be reproduced; nor does the waiver extend to quotation of whatever length presented as primary material for its own sake (as in anthologies or books of readings).

"4. The fact that specific permission for quoting of material may be waived under this agreement does not relieve the quoting author and publisher from the responsibility of determining 'fair use' of such material."-Antiquarian Bookman, May 28-June 4, 1962, p. 2118. 